\title{
Exploring the Ambiguity of Operation Sophia Between Military and Search and Rescue Activities
}

\author{
Giorgia Bevilacqua
}

\section{Introduction}

On 17 February 2016, WikiLeaks released the first six monthly Report concerning the performed and planned phases of Eunavfor Med Operation Sophia (Six Monthly Report). ${ }^{1}$ This is an ongoing military mission that was recently undertaken by the European Union (EU) to disrupt the business model of migrant smuggling and human trafficking networks in the Mediterranean (hereinafter Operation Sophia). ${ }^{2}$

One of the main challenging elements within the Six Monthly Report is the planned but still pending transition from the phase involving enforcement actions on the high seas to the subsequent phase involving the exercise of the same enforcement actions also in the territorial and internal waters of Libya. ${ }^{3}$ The rationale of the entry of naval forces up to the Libyan coastline is to intercept alleged criminals before they depart. ${ }^{4}$ And, in effect, the vast majority of

\footnotetext{
${ }^{1}$ See Eunavfor Med Op Sophia (2016)—Six Monthly Report 22 June-31 December 2015. Available via WikiLeaks https://wikileaks.org/eu-military-refugees/EEAS/EEAS-2016-126.pdf. Accessed 31 May 2016.

${ }^{2}$ The Operation was initially titled 'EUNAVFOR MED' and was subsequently renamed 'EUNAVFOR MED operation SOPHIA' after a baby girl who was given birth to by a woman of Somali origin on a European vessel in the summer months of 2015 after being rescued. See Council Decision (CFSP) 2015/778 of 18 May 2015 on a European Union military operation in the Southern Central Mediterranean, Official Journal (2015) L 122/31 and Council Decision (cfsp) 2015/1926 of 26 October 2015 amending Decision (CFSP) 2015/778 on a European Union military operation in the Southern Central Mediterranean Official Journal (2015) L 281/13.

${ }^{3}$ See the Six Monthly Report, pp. 3 and 18.

${ }^{4}$ On the need to have forces close to the Libyan shore, see Lehmann (2015).

G. Bevilacqua $(\bowtie)$

Institute for Research on Innovation and Services for Development, Italian National Research

Council, Naples, Italy

e-mail: g.bevilacqua@iriss.cnr.it
} 
undocumented migrants, refugees, and asylum seekers (hereinafter generically referred to as irregular migrants), ${ }^{5}$ who attempt to cross the Mediterranean sea, depart from Libya, ${ }^{6}$ where the volatile government situation and the consequent inability to control the territory are contributing to facilitate the development of the two distinct criminal phenomena of migrant smuggling ${ }^{7}$ and human trafficking. ${ }^{8}$ These two different phenomena in the hands of transnational criminal networks share the common feature of exploiting the migratory movements for personal gains and disregard for human life. In practice, what smugglers and traffickers do is to offer a transportation service to hundreds of thousands of persons who crossed many borders already, mainly in African and Middle Eastern countries, and take advantage of the fact that the only concern of these persons is to flee from their countries of origin by whatever means possible, accepting the risk of sinking, and, indeed, many do sink. ${ }^{9}$

In light of this complex and tragic scenario, this chapter aims to explore the ambiguity of Operation Sophia, focusing on two sensitive and interrelated aspects: the use of coercive powers against suspected smugglers and traffickers and the rescue of migrants carried out by naval forces at sea. To this end, we will first introduce the operational and legal background in which the EU operates within the

\footnotetext{
${ }^{5}$ According to the United Nations High Commissioner for Refugees (UNHCR), in 2015 over 80 percent of the irregular migrants came from the world's top 10 refugee-producing countries, including Syria, Afghanistan, Eritrea, and Iraq. Available via UNHCR http://data.unhcr.org/ mediterranean/regional.php. Accessed 31 May 2016. On the different definitions of 'irregular immigrants', see Trevisanut (2012), pp. 1-22.

${ }^{6}$ The Six Monthly Report, p. 6.

${ }^{7}$ Pursuant to Art. 3 of the Protocol against the Smuggling of Migrants by Land, Sea and Air, the Smuggling of migrants is: 'the procurement, in order to obtain, directly or indirectly, a financial or other material benefit, of the illegal entry of a person into a State Party of which the person is not a national or a permanent resident'. See the Protocol against the Smuggling of Migrants, supplementing the United Nations Convention against Transnational Organized Crime, New York, 15 November 2000, in United Nations Treaty Series, Vol. 2241, Doc. A/55/383, p. 507. ${ }^{8}$ Pursuant to Art. 3 of the Protocol to Prevent, Suppress and Punish Trafficking in Persons, especially Women and Children, the Trafficking in persons is: 'the recruitment, transportation, transfer, harboring or receipt of persons, by means of the threat or use of force or other forms of coercion, of abduction, of fraud, of deception, of the abuse of power or of a position of vulnerability or of the giving or receiving of payments or benefits to achieve the consent of a person having control over another person, for the purpose of exploitation. Exploitation shall include, at a minimum, the exploitation of the prostitution of others or other forms of sexual exploitation, forced labour or services, slavery or practices similar to slavery, servitude or the removal of organs'. See the Protocol to Prevent, Suppress and Punish Trafficking in Persons, especially Women and Children, supplementing the United Nations Convention against Transnational organized Crime, New York, 15 November 2000, in United Nations Treaty Series, Vol. 2237, Doc. A/55/383, p. 319.

${ }^{9}$ By way of example, in October 2013 an overcrowded boat carrying asylum seekers from Eritrea, Somalia and Ghana capsized within sight of Italy's shores. Despite the vessel's stated capacity of 35 passengers, it carried around 500 souls on board that night. For 360 of them, dreams of a better life away from poverty and war died in the depths of the Mediterranean, see BBC: http://www.bbc. com/news/world-europe-24440908. Accessed 31 May 2016.
} 
area of immigration at sea, assessing, in particular, the main relevant characteristics both of the civilian (Sect. 2.1) and military operations (Sect. 2.2) recently adopted in the Central Mediterranean Route. As the Operation Sophia's mandate stipulates that the activation of its crucial phase in the territorial waters of Libya requires an authorization of the United Nations Security Council (Security Council) or the consent of Libya, we will then assess whether and, eventually, under which conditions military assets are allowed to exercise coercive powers against vessels suspected of being used for migrant smuggling and human trafficking. ${ }^{10}$ The analysis will consider the different legal regimes that may apply in the different jurisdictional marine areas and, specifically, on the high seas (Sect. 3.1) and in the territorial sea (Sect. 3.2). Furthermore, since naval forces may be and frequently are called upon saving human lives at sea, ${ }^{11}$ we will verify the content and the legal framework of the positive obligation to render assistance to people in distress at sea (Sect. 4), as well as the complex risks raised by search and rescue (SAR) interventions and disembarkation procedures, especially when these activities are undertaken in cooperation with third countries (Sect. 5). The conclusions contain some remarks on the EU military mission and, more in general, on the role played by the EU and its Member States in the Mediterranean Sea in order to manage the phenomenon of irregular immigration by sea (Sect. 6).

\section{The Engagement of the EU in SAR Activities: A Missed Opportunity}

For the purpose of managing the Mediterranean migration crisis, a wide number of different routes have been undertaken at national and European levels. While in the past immigration control programs were implemented unilaterally and exclusively by the most affected coastal States, in the last decade an increasing role has been played by Europe. The following illustrates the relevant background of Frontex Joint Operations (Sect. 2.1) and of the new EU Operation Sophia (Sect. 2.2).

\footnotetext{
${ }^{10}$ The mandate of Operation Sophia refers to 'human smuggling or trafficking', whereas the established terminology in international law for these two criminal phenomena is 'smuggling of migrants' and 'trafficking of persons'. See Art. 3 of the Protocol against the Smuggling of Migrants and Art. 3 of the Protocol against the Trafficking in Persons, cit.

${ }^{11}$ On recent salvage operations carried out by military forces, see EEAS: http://www.eeas.europa. eu/csdp/missions-and-operations/eunavfor-med/news/index_en.htm. Accessed 31 May 2016.
} 


\subsection{Frontex Joint Operations}

Since 2005, the EU has been dealing with migration by sea through the European Agency for the Management of Operational Cooperation at the External Borders of Member States of the European Union (Frontex). ${ }^{12}$ One of its most important competences is to plan, coordinate, implement, and evaluate Member States' border control and surveillance activities through the so-called Joint Operations at the EU external borders (sea, land, and air). In the past years, as a result of these operations, hundreds of irregular migrants, while attempting to cross the European external maritime border, rather than being saved, have been forced to return to the State from which they departed or were presumed to have departed. ${ }^{13}$

The main focus of Frontex Joint Operations remained essentially the same over the years, but some steps forward toward an increasing engagement in SAR activities have been slowly undertaken. Rather important in this context is the adoption of EU Regulation No. 656/2014 (Sea Border Regulation), ${ }^{14}$ which is the result of a laborious series of negotiations and institutional issues. ${ }^{15}$ It replaced Council Decision 2010/252/EU, ${ }^{16}$ which was entirely annulled by the European Court of Justice in September 2012. The provisions laid down in the challenged Decision contained essential elements of the surveillance of the sea external borders of the Member States and constituted "a major development" in the Schengen Borders Code system. ${ }^{17}$ Moreover, according to the Court of Luxembourg, these

\footnotetext{
${ }^{12}$ Frontex was established by Council Regulation (EC) 2007/2004 establishing a European Agency for the Management of Operational Cooperation at the External Borders of the Member States of the European Union (EU). This Regulation was later amended by the Regulation (EC) No 863/2007 of 11 July 2007 establishing a mechanism for the creation of Rapid Border Intervention Teams and amending Council Regulation (EC) No 2007/2004 as regards that mechanism and regulating the tasks and powers of guest officers. It was then amended by the Regulation (EU) No 1168/2011 of 25 October 2011 amending Council Regulation (EC) No 2007/2004 establishing a European Agency for the Management of Operational Cooperation at the External Borders of the Member States of the EU.

${ }^{13}$ On the practice of 'push-backs' in the Mediterranean, see the European Court of Human Rights, Hirsi Jamaa and others v. Italy, Judgment of 23 February 2012; See Borelli and Stanford (2014), pp. 29-69.

${ }^{14}$ See Regulation (EU) No. 656/2014 of the European Parliament and of the council of 15 May 2014 establishing rules for the surveillance of the external sea borders in the context of operational cooperation coordinated by the European Agency for the Management of Operational Cooperation at the External Borders of the Member States of the European Union, in Official Journal of the European Union L 189/93.

${ }^{15}$ For further considerations on the negotiations and institutional conflicts within the EU, see den Heijer (2016), pp. 53-71.

${ }^{16}$ See Council (2010), Decision 2010/252/EU of 26 April 2010 supplementing the Schengen Borders Code as regards the surveillance of the sea external borders in the context of operational cooperation coordinated by Frontex at the external borders of the Member States of the EU, OJ L 111/20, 04.05.2010.

${ }^{17}$ The Schengen Borders Code applies to any person crossing the external borders of all EU countries, except those of the United Kingdom and Ireland, and the internal borders of the
} 
provisions entailed political choices and questions over fundamental rights. For these reasons, their adoption must fall "within the responsibilities of the European Union legislature" and require the ordinary legislative procedure and not the comitology procedure. ${ }^{18}$ During the subsequent legislative process that finally brought to the adoption of the Sea Border Regulation, the Member States have accepted the EU's involvement in SAR activities, but only as far as it remains limited to Frontex Joint Operations. ${ }^{19}$

The first Joint Operation to which the Sea Border Regulation was applied is the Operation Triton. It was actually launched in October 2014 in order to solve the struggle between Italy and the EU over a follow-up to the Italian SAR operation Mare Nostrum. And, even though the operational area and main activities of Triton were initially very limited in scope, in the aftermath of two grave shipwrecks in April 2015, Frontex adopted a new operational plan. ${ }^{20}$ The latter expanded its mission with an increased budget, additional assets and an extended operational area from 30 up to 138 nautical miles south of Lampedusa, almost reaching the extent that had been covered earlier by Mare Nostrum. ${ }^{21}$ The expansion of this Frontex' operation could be seen as an implicit admission of guilt by the EU for its deadly policy of retreat and for its passive role toward the frequent drownings. The Mediterranean Sea has been defined as a firm and fatal dividing border between "North" and "South"; according to the International Organization for Migration, since the year 2000, close to 25,000 migrants have perished in the Mediterranean, making it the world's deadliest border. ${ }^{22}$ In practice, however, Triton remained first and foremost a border control operation, whereas rescue activities continue to be incidental and a secondary task of this primary mission.

\footnotetext{
Schengen Area, a border-free area comprising 22 EU countries, along with Iceland, Liechtenstein, Norway and Switzerland.

${ }^{18}$ See Court of Justice of the European Union (Grand Chamber) (2012), Judgment of 5 September 2012, Case C-355/10, Parliament v Council, par. 65-85. For a comment on the case, see Andreone (2014).

${ }^{19}$ See Carrera and den Hertog (2016), pp. 1-20.

${ }^{20}$ For practicalities on Frontex support to SAR activities, see http://ec.europa.eu/dgs/home-affairs/ what-we-do/policies/european-agenda-migration/background-information/docs/

frontex_triton_factsheet_en.pdf.

${ }^{21}$ On the expiration of Frontex Joint Operation Triton, see Frontex: http://frontex.europa.eu/news/ frontex-expands-its-joint-operation-triton-udpbHP. Accessed 31 May 2016.

${ }^{22}$ See International Organization for Migration (IOM), Migration Trends Across the Mediterranean: Connecting the Dots, June 2015, p. 1. Available via IOM file://C:/Users/win/Downloads/ Altai_Migration_trends_accross_the_Mediterranean.pdf. Accessed 31 May 2016.
} 


\subsection{The Novel EU Engagement in Operation Sophia}

The adoption of the second edition of the Triton operation was accompanied by the deployment of an EU novel undertaking at sea. Having regard to Art. 42 of the EU Treaty and to the proposal from the High Representative of the Union for Foreign Affairs and Security Policy, on 18 May 2015 the Council adopted Decision No. 2015/778 (Council Decision) approving the Crisis Management Concept for a Common Security and Defense Policy operation. ${ }^{23}$ This is part of the EU's comprehensive approach to migration and, as anticipated in the introduction, constitutes the military response designated to tackle the business model of migrant smuggling and human trafficking in the Southern Central Mediterranean.

The Council Decision is a non-legislative act adopted on an intergovernmental basis by the Council and represents the legal instrument that sets out the purpose of the mission, its mandate, and other practical information on how Operation Sophia shall be handled. ${ }^{24}$ With specific respect to its mandate, the mission aims to identify, capture, and dispose vessels and assets used or suspected of being used by smugglers and traffickers. The mission is intended to be conducted in three sequential phases, and the Political and Security Committee has the power to decide on the transition between the different phases, subject to the assessment of the Council. ${ }^{25}$ Whereas the first phase, which was completed from 22 June to 7 October 2015, was focused on the surveillance and assessment of existing smuggling and trafficking networks, ${ }^{26}$ the two subsequent phases involve the exercise of real enforcement actions against the boats carrying irregular migrants. More specifically, pursuant to Art. 2 of the Council Decision, Phase 2 consists of two distinct subphases: (1) a phase that includes "boarding, search, seizure and diversion" of suspected boats on the high seas (Phase 2-High Seas) ${ }^{27}$ and (2) a phase that includes "boarding, search, seizure and diversion" of suspected boats in the territorial and internal waters of Libya (Phase 2-Libyan Territorial Sea) ${ }^{28}$ Finally, the third phase, would enable Eunavfor Med forces to "take all necessary measures" against suspected vessels, "including through disposing of them or rendering them inoperable," in the territory of the coastal State concerned, i.e., in Libyan territorial and internal waters, in its ports, and in its coastal areas. ${ }^{29}$

\footnotetext{
${ }^{23}$ See Council Decision (CFSP) 2015/778 of 18 May 2015 on a European Union military Operation in the Southern Central Mediterranean, cit.

${ }^{24}$ For details on the legal framework governing the adoption of Operation Sophia, see Butler and Ratcovich (2016), pp. 235-259.

${ }^{25}$ See Council Decision (CFSP) 2015/972 of 22 June 2015 launching the European Union military operation in the southern Central Mediterranean, Official Journal (2015) L 157/51.

${ }^{26}$ See Art. 2.2(a) of the Council Decision.

${ }^{27}$ See Art. 2.2(b)(i) of the Council Decision.

${ }^{28}$ See Art. 2.2(b)(ii) of the Council Decision.

${ }^{29}$ See Art. 2.2(c) of the Council Decision.
} 
It is noteworthy that the Operation has obtained an extensive support from EU Member States. Since the EU cannot rely on any military personnel or weaponry on its own, the Operation is reliant upon 22 contributing Member States. ${ }^{30}$ The Operation's Headquarter has been established in Rome, and the Rear Admiral of the Italian Navy has been appointed as the Operation Commander.

Within the field of immigration at sea, whereas the EU remains focused on the protection of the security of internal and external borders, the target of EU operations has - at least formally-changed. Indeed, whereas previous Frontex pushback operations were addressed to irregular migrants as such, the new EU naval operation in the Mediterranean $\mathrm{Sea}^{31}$ is addressed to migrant smugglers and human traffickers. Meanwhile, however, the full engagement of the EU in a real salvage mission remains a missed opportunity.

\section{Enforcement Jurisdiction Against Vessels Suspected of Migrant Smuggling and Human Trafficking and the Difficult Transition to Phase 2 into the Libyan Territorial Sea}

Following the political guidance provided by the defense and foreign affair ministers at their informal meetings in September 2015, the EU Council established that the conditions for Phase 2 of the Operation Sophia were met but only insofar as actions in international waters are concerned. ${ }^{32}$ In what follows, we will take a closer look at the legal framework applicable to Phase 2-High Seas and Phase 2Libyan Territorial Sea of the Operation. For these subphases, the Council Decision stipulates different legal conditions that require distinct considerations and assessments. Notably, when conducting "boarding, search, seizure and diversion" of suspected vessels on the high seas, naval forces shall act in accordance with the conditions provided for by applicable international law, including the 1982 United

\footnotetext{
${ }^{30}$ The Member States participating to the mission as contributing states are: Belgium, Bulgaria, Cyprus, Czech Republic, Spain, Estonia, Finland, France, Germany, Great Britain, Greece, Hungary, Italy, Latvia, Lithuania, Luxemburg, Malta, the Netherlands, Poland, Rumania, Slovenia Sweden.

${ }^{31}$ Distant from European shores, the first EU naval mission 'EUNAVFOR' was launched in the Gulf of Aden off the Eastern coast of Africa in 2008 in order to combat piracy and armed robbery at sea. See the EU Council, Joint Action 2008/851/CFSP of 10 November 2008 on a European Union military operation to contribute to the deterrence, prevention and repression of acts of piracy and armed robbery off the Somali coast, 10 Nov. 2008, Official Journal (2008) L301/33. For doctrine, see Geiss and Petrig (2011), p. 18.

${ }^{32}$ On 28 September 2015, the Political and Security Committee adopted Decision (CFSP) 2015/ 1772 concerning the transition by EUNAVFOR MED operation SOPHIA to the second phase of the operation, as provided for in point (b)(i) of Article 2(2) of Decision (CFSP) 2015/778 which also approved adapted Rules of Engagement for that phase of the operation, OJ L 258, 3.10.2015.
} 
Nations Convention on the Law of the Sea (UNCLOS) ${ }^{33}$ and the Protocol against the Smuggling of Migrants. ${ }^{34}$ Differently, when operating in territorial or internal waters, foreign naval forces shall act in accordance with any applicable Security Council Resolution or consent by the coastal State concerned, i.e., Libya.

With the aim of assessing whether and, eventually, under which conditions military assets are allowed to exercise enforcement jurisdiction in the different marine zones against vessels suspected of being engaged in migrant smuggling and human trafficking, the following section identifies and analyzes the legal framework that is applicable both on the high seas (Sect. 3.1) and in Libyan territorial and internal waters (Sect. 3.2).

\subsection{On the High Seas}

When sailing at sea, ships are subject to the jurisdiction of their flag State, whose exercise differs according to the maritime zone in which the ship is sailing. ${ }^{35}$ As a ship sails away from a State's coastline, the extent of jurisdiction shifts in favor of the flag State, until it becomes exclusive on the high seas. Conversely, as the ship approaches a State's coastline, the balance shifts in favor of the coastal State. In this regard, the basic legal framework is set by the UNCLOS. Its provisions stipulate the current division in maritime zones and codify States' jurisdiction, including the jurisdiction to enforce. ${ }^{36}$ In particular, as far as the high seas is concerned, the UNCLOS codifies the following relevant customary principles of international law of the sea: the principle of the freedom of navigation and the principle of the exclusive jurisdiction of the flag State. On the high seas, by virtue of these principles, ships are free to navigate ${ }^{37}$ and are subject to the exclusive jurisdiction of the flag State, ${ }^{38}$ and no claims of sovereignty can be validly put forward by any State. $^{39}$

In exceptional circumstances, however, pursuant to Art. 110 UNCLOS, "a warship which encounters on the high seas a foreign ship" may exercise the boarding of a suspected foreign private ship. ${ }^{40}$ Excluding the relevance of the

\footnotetext{
${ }^{33}$ The United Nations Convention on the Law of the Sea (UNCLOS) was signed on 10 December 1982, in Montego Bay, entered into force on 16 November 1994 and was ratified by 165 States as of 19 July 2013, in United Nations Treaty Series, Vol. 1833, p. 3.

${ }^{34}$ For references on the Protocol against the Smuggling of Migrants, cit.

${ }^{35}$ See Ringbom (2015), pp. 1-454.

${ }^{36}$ On the provisions of international law of the sea applicable to immigration in the different marine jurisdictional zones, see Scovazzi (2014), p. 216.

${ }^{37}$ See Art. 87 of the UNCLOS (Freedom of the high seas).

${ }^{38}$ See Art. 92 of the UNCLOS (Status of ships).

${ }^{39}$ See Art. 89 of the UNCLOS (Invalidity of claims of sovereignty over the high seas).

${ }^{40}$ See Art. 110 of the UNCLOS (Right of visit).
} 
case in which the ship is engaged in piracy, ${ }^{41}$ the first case of the list laid down in Art. 110 UNCLOS that deserves attention is the case of "slave trade." 42 In theory, since trafficking in persons is often referred to as a modern form of slavery, ${ }^{43}$ this norm may be used as a specific legal basis for exercising the right to visit against vessels suspected of this crime. In practice, however, this legal basis may appear quite weak, at least because the exception concerning ships engaged in slavery trade has never been used for previous cases of human trafficking yet. Moreover, when operating at sea, it might be hard to identify and distinguish quickly the cases of migrant smuggling from the case of human trafficking. Accordingly, it would be safer to use a stronger legal basis applicable to both criminal phenomena.

In effect, a stronger legal basis may be found in Art. 110(d) UNCLOS, which considers the case in which there is reasonable grounds for suspecting "that a ship is without nationality." 44 Since the boats used for irregular migration in the Mediterranean Sea are very often non-registered small vessels without any flag, the exception concerning the absence of nationality may represent a very useful instrument for exercising the boarding of the suspected vessels. Furthermore, we believe that government vessels may also be entitled to act beyond the right of visit. Article 110 UNCLOS does not explicitly allow the exercise of additional coercive powers, but at the same time it does not prohibit them. ${ }^{45}$

The approach taken by the UNCLOS, which is mainly based on the freedom of navigation on the high seas and on the exclusive jurisdiction of the flag State, is not substantially changed by the more recent Protocol against the Smuggling of Migrants, ${ }^{46}$ which is also recalled in the Council Decision. ${ }^{47}$ Specifically, under Art. 8(7) of this Protocol, on the high seas the boarding of the suspected ships can take place only after having received authorization by the flag State, unless the ship suspected of migrant smuggling is without nationality. In addition, Art. 8(7) stipulates that "[i]f evidence confirming the suspicion is found, [the] State Party shall take appropriate measures." Such "appropriate measures" may be interpreted as those necessary to exercise further enforcement powers in order to act beyond the boarding of the suspected vessel, ${ }^{48}$ provided that such powers are exercised "in accordance with relevant domestic and international law."49

\footnotetext{
${ }^{41}$ See Art. 110(a) UNCLOS.

${ }^{42}$ See Art. 110(b) UNCLOS.

${ }^{43}$ See Siller (2016), pp. 405-427; Scarpa (2008).

${ }^{44}$ See Art. 110(d) UNCLOS.

${ }^{45}$ See Papanicolopulu (2016), pp. 2-22.

${ }^{46}$ See Scovazzi (2014), cit.

${ }^{47}$ The Protocol against the Smuggling of Migrants, cit.

${ }^{48}$ See Papanicolopulu (2016) cit.

${ }^{49}$ For a thorough analysis on the criteria for a lawful exercise of the use of force at sea in accordance with human rights law, see International Tribunal for the Law of the Sea, The $M / V$ "Saiga" (No. 2) Case (Saint Vincent and the Grenadines v. Guinea), Judgment of 1 July 1999D. For doctrine, see Guilfoyle (2009), p. 268.
} 
Differently, the 2000 Protocol to Prevent, Suppress and Punish Trafficking in Persons, especially Women and Children, supplementing the United Nations Convention against Transnational Organized Crime, ${ }^{50}$ is silent on enforcement measures that can be exercised at sea.

The analysis of the above-recalled international legal framework clarifies that naval forces that encounter on the high seas a suspected private foreign ship are justified in boarding it if the flag State of the ship suspected of migrant smuggling or human trafficking has given its express authorization, if there is reasonable grounds for suspecting that the ship is without nationality, or when the suspect is of trafficking in human beings, that is, engaged in slave trade. ${ }^{51}$

\subsection{In Territorial Waters}

The launch of the Operation in Libyan Territorial Sea would be extremely important as criminals would be intercepted before they depart and, in turn, before they jeopardize the lives of hundreds of persons. However, while the transition to Phase 2-High Seas was not problematic, conversely the transition to the subsequent Phase 2-Libyan Territorial Sea is not immune from challenges as the Council Decision requires either a Security Council mandate or the consent of Libya.

\subsubsection{The UN Security Council Resolution}

With respect to the first alternative condition required by the Operation Sophia's mandate, according to the powers granted by Articles 39 and 42 of the United Nations Charter (UN Charter), the Security Council may authorize the use of force, whenever it determines "the existence of any threat to the peace, breach of the peace, or aggression." 52 The notion of obtaining the support of the United Nations, in the absence of authorization by the State concerned, is in line with a consolidated State practice of past decades, according to which UN Member States attempted to

\footnotetext{
${ }^{50}$ The Protocol to Prevent, Suppress and Punish Trafficking in Persons, especially Women and Children, cit.

${ }^{51}$ Even if the analysis in the text is restricted to the international legal framework, it seems worth noting that with respect to enforcement jurisdiction on the high seas some issues may be raised by the domestic legal systems which may restrict the jurisdiction against migrant smugglers to the territorial sea. For doctrine, see Andreone (2011), pp. 183-188. With respect to the Italian system, more recently, the Supreme Court has affirmed that against ships without nationality encountered on the high seas, coercive powers can be exercised on the basis of a valid reason, such as art. 8 of the Protocol against Smuggling of Migrants. See Corte di Cassazione, judgment of 23 May 2014, No. 36052 .

${ }^{52}$ See Articles 39 and 42 of the UN Charter. For doctrine on the powers of the UN Security Council, see Conforti, Focarelli (2015).
} 
legitimize unilateral interventions through the label of Security Council resolutions adopted under Chapter VII of the UN Charter. ${ }^{53}$

On 11 May 2015, the High Representative of the Union for Foreign Affairs and Security Policy has officially informed the Security Council of the need for the EU to work with its support in order to manage the Mediterranean migration crisis. ${ }^{54}$ The UN bodies, however, have often stressed the importance of focusing the European action on saving lives when dealing with migration rather than on military actions. ${ }^{55}$ The negotiations between the EU and the UN ended with a strange compromise: with 14 votes in favor and one abstention, ${ }^{56}$ acting under Chapter VII of the UN Charter, the Security Council has adopted a Resolution to maintain international peace and security, condemning, in particular, "all acts of migrant smuggling and human trafficking into, through and from the Libyan territory and off the coast of Libya, which undermine further the process of stabilization of Libya and endanger the lives of thousands of people."

In the view of the EU institutions, the Resolution "reinforces the authority to take measures against the smuggling of migrants and human trafficking from the territory of Libya and off its coast." ${ }^{58}$ Conversely, we would minimize the relevance of the Resolution since it is hard to identify the legal rationale behind its adoption. As requested by Russia at the UN Security Council's preparatory meetings, ${ }^{59}$ the mandate of the Resolution covers only the high seas off the coasts of Libya, rather than the Libyan territorial sea. ${ }^{60}$ As seen above (Sect. 3.1), in this marine zone, naval forces can already act against stateless ships in accordance with the applicable provisions both of the UNCLOS and the Protocol against the Smuggling of Migrants. ${ }^{61}$ Moreover, even though the Resolution may, in theory,

\footnotetext{
${ }^{53}$ On the unilateral use of force, see Picone (2015), pp. 3-32.

${ }^{54}$ See the Council Decision, Rec. 4.

${ }^{55} \mathrm{See}$, for instance, the speech of the UN Secretary-General, Ban Ki-Moon, at the European Parliament in plenary session on 27 May 2015. Available via European Parliament News http:// www.europarl.europa.eu/news/en/news-room/20150526STO59634/Ban-Ki-moon-on-migration$\%$ E2\%80\%9CSaving-lives-should-be-the-top-priority\%E2\%80\%9D. Accessed 31 May 2016.

${ }^{56}$ The abstention was of Venezuela.

${ }^{57}$ See Resolution 2240 (2015), adopted by the Security Council at its 7531st meeting, on 9 October 2015, Doc. S/RES/2240 (2015), para. 1.

${ }^{58}$ On the perspective of the EU, see Political and Security Committee Decision (CFSP) 2016/118 of 20 January 2016, concerning the implementation by Eunavfor Med Operation Sophia of United Nations Security Council Resolution 2240 (2015) (Eunavfor Med Operation SOPHIA/1/2016, Rec. 3; A similar approach on the Resolution 2240 (2015) is used by the Operation Commander in the Six Monthly Report, p. 10, cit.

${ }^{59}$ On the express request of Russia, see the Security Council meeting records adopted at the 7531st meeting on 9 October 2015, Doc. S/PV.7531 and the Press Release of the Security Council Resolution 2240 (2015), including Statements after action. Available via United Nations Meetings Coverage and Press Releases: http://www.un.org/press/en/2015/sc12072.doc.htm. Accessed 31 May 2016.

${ }^{60}$ See Resolution 2240 (2015), cit., para. 7.

${ }^{61}$ See the Protocol against the Smuggling of Migrants, cit.
} 
extend the possibility to intervene to suspected vessels that fly the flag of a third State, in practice, according to the current modus operandi of suspected criminals who act in the Mediterranean sea, the vast majority of the vessels used by them are stateless vessels. ${ }^{62}$ Furthermore, the Resolution does not appear to be a blanket mandate authorizing the use of force as resolutions adopted under Chapter VII usually are. Indeed, if there is confirmation that the vessels are being used for migrant smuggling or human trafficking, "all measures commensurate to the specific circumstances" can be used. This is not an authorization to use "all necessary measures" in confronting migrant smugglers and human traffickers, which was the wording originally adopted in the initial draft of the Resolution circulated by the United Kingdom. The unusual expression ultimately adopted in the final version of Resolution 2240 (2015) is the result of the amendments wanted by some Security Council Member States concerned that the Resolution could mean, as it namely means in the language generally used by the Security council, a blanket mandate to the use of force. ${ }^{63}$

Allegedly, notwithstanding the adoption of the Security Council Resolution, the essential parts of Operation Sophia's mandate risks to remain unaccomplished, unless Libya decides to authorize the international fight against migrant smugglers and human traffickers.

\subsubsection{The Consent of Libya}

The second alternative route identified by the Council Decision consists of the consent of Libya. In this respect, the legal analysis revolves around the principle of territorial sovereignty. The boarding, search, seizure, and diversion activities envisioned by the Operation's mandate are, indeed, enforcement measures that may involve the use of coercive powers. ${ }^{64}$ The exercise of such powers by foreign authorities may interfere with the fundamental principle of territorial sovereignty. This principle of general international law is codified also by the UNCLOS. The latter specifically provides that States have full sovereignty within their territorial waters, which may extend up to 12 nautical miles from the baselines. ${ }^{65}$ In this marine area, the coastal State enjoys the exclusive right to exercise coercive powers just like on the territory of the mainland. Accordingly, the principle of territorial

\footnotetext{
${ }^{62}$ On the question of jurisdiction over suspected vessels, see Papastavridis (2016b).

${ }^{63}$ See Vote on a Resolution on Human Trafficking and Migrant Smuggling in the Mediterranean. In What's in Blue. Insights on the Work of the UN Security Council, 8 October 2015. Available via What's in Blue http://www.whatsinblue.org/2015/10/vote-on-a-resolution-on-human-traffickingand-migrant-smuggling-in-the-mediterranean.php. Accessed 31 May 2016.

${ }^{64}$ See Art. 2 of the Council Decision.

${ }^{65}$ See Articles 2-4 of the UNCLOS.
} 
sovereignty does not allow for other States to participate in this exercise, unless expressly authorized. $^{66}$

The EU has been seeking to obtain the consent to enter Libyan territorial sea, but up to now Libyan authorities did not appear as willing to provide such authorization. The international relationships are clearly complicated by the fact that since 2014, Libya has been facing a grave political crisis and, as a consequence of such crisis, Libyan authorities lack the capacity to effectively control their territory, as well as their territorial sea.

The current political scenario may probably change in light of the recent UN-led formation of a government of national unity, which, according to the Security Council Resolution 2259 (2015), is the sole legitimate Government of Libya. ${ }^{67}$ Accordingly, only this government would be considered by the International Community as the authority legitimate to authorize the entry into Libyan territorial waters for the purpose of disrupting the business model of migrant smuggling and human trafficking. This legal option may find support in a precedent case and, specifically, in the context of the international response to maritime piracy in Somalia. Over 20 years, Somalia has lacked any functioning institutions or any form of political control of the territory, to the extent of being defined by the literature as the locus classicus of a failed State. ${ }^{68}$ In 2004, after nearly 2 years of insidious negotiations and numerous international attempts to deal with the problem of the crisis of sovereignty, a provisional transition federal government (TFG) was formed. The latter was a highly precarious body held together artificially by the UN and, at the same time, the sole Somali government recognized by the International Community. Likewise, in Libya, the political instability of Somalia contributed to the fervent and atrocious resurgence of a violent crime, i.e., maritime piracy. In order to address this phenomenon, the TFG (replaced in 2012 by the new Somali Authorities) explicitly asked for international assistance. ${ }^{69}$ In light of this request and thus in light of the TFG's consent, a number of Security Council resolutions were adopted to ensure the implementation of the rules of international law concerning coercive powers against piracy on the high seas also in the territorial sea and even on the mainland of Somalia.

\footnotetext{
${ }^{66}$ For a thorough analysis on the relevance of the State's consent, see Wippman (1996), p. 209; with specific reference to the coastal State's consent in the context of piracy in Somalia, see Treves (2009), p. 406; Tancredi (2008), p. 937.

${ }^{67}$ See Resolution 2259 (2015), adopted by the Security Council at its 7598th meeting, on 23 December 2015, Doc. S/RES/2259 (2015), para. 3.

${ }^{68}$ For a reconstruction of the Somali crisis, for doctrine see Gordon (1997), pp. 903-974; Kreijen (2004), p. 65 ff.; for case-law see European Court of Human Rights, Sufi and Elmi vs. United Kingdon, Apps. No. 8319/07 and 11449/07, concerning the appeal by two Somali citizens at risk of inhumane treatment if returned to Mogadishu.

${ }^{69}$ According to paragraph 9 of Resolution 1816 (2008) 'the authorization set out in paragraph 7' has been provided only following receipt of the letter from the Permanent Representative of the Somalia Republic to the United Nations to the President of the Security Council dated 27 February 2008 conveying the consent of the TFG'. Similar formulations, referring to further letters conveying the consent of the TFG, are in Security Council Resolutions 1846 (2008) and 1851 (2008).
} 
It is probably bearing in mind the Somali precedent that the Operational Commander states in the above recalled Six Monthly Report on Operation Sophia that "In order to move to phase 2 in Libyan territorial waters, we need firstly an invitation from the GNA [Government of National Accord], as the sole legitimate Government of Libya under UNSCR 2259 (2015), and secondly a UN Security Council Resolution to provide the necessary legal mandate to operate". 70

\section{Between the Need and the Obligation to Turn into a Rescue Scheme}

At the current state of play, following Operation Sophia's entry into Phase 2-High Seas, criminals suspected of migrant smuggling and human trafficking appear to enjoy less freedom of maneuver. The geographical limits of the Operation forced them to act in the Libyan territorial sea where, however, they may act uncontrolled as national authorities are not capable to prevent and repress their criminal actions. And while alleged smugglers and traffickers are remaining within the national borders, smuggled and trafficked persons are left on unsafe boats with limited food, water, and, above all, insufficient fuel to reach anywhere further than 30-50 nautical miles from the Libyan coast. ${ }^{71}$

By consequence, Operation Sophia is often turned into a salvage mission. According to the Six Monthly Report, as of 31 December 2015, military forces have completed the rescue of more than 8336 persons, initiated both by detection of boats in distress by military assets or by request from the Rescue Coordination Centre in Rome. ${ }^{72}$ Also in 2016, the Operation is often turned into a rescue mission that saved hundreds of migrants at sea while they were attempting the Central Mediterranean route to Europe. ${ }^{73}$

The relevance of the duty to render assistance is expressly recalled both in the Council Decision and Resolution 2240 (2015). Specifically, Recital (6) of the Council Decision ${ }^{74}$ stipulates that the Operation shall be conducted in accordance with international law and, in particular, with the relevant provisions of the UNCLOS, the Safety of Life at Sea Convention (SOLAS Convention), ${ }^{75}$ and the

\footnotetext{
${ }^{70}$ See the Six Monthly Report, section on Legal mandate-UNSCR and Libyan Invitation, p. 19.

${ }^{71}$ Ibid, Section on Tactics, Techniques and Procedures (TTP) Evolution, p. 7. For a description of the conducts of smugglers and traffickers, see also Cataldi (2015), pp. 1498-1502; in particular, the author examines the decision of the Italian Supreme Court, Criminal proceedings against Radouan Hai Hammouda, No. 3345, 23 January 2015.

${ }^{72}$ Ibid, Section on Phase II.A (High Seas) Activities, p. 11.

${ }^{73}$ On more recent news, see EU External Action: http://www.eeas.europa.eu/csdp/missions-andoperations/eunavfor-med/news/index_en.htm (5/16).

${ }^{74}$ See Council Decision, cit.

${ }^{75}$ The International Convention for the Safety of Life at Sea, adopted 1 November 1974, in force 25 May 1980; 1184 UNTS No. 1861.
} 
Maritime SAR Convention, ${ }^{76}$ which include the obligation to assist persons in distress at sea. More intensively, the Security Council affirms "the necessity to put an end to the recent proliferation of, and endangerment of lives by, the smuggling of migrants and trafficking of persons in the Mediterranean Sea off the coast of Libya" ${ }^{, 77}$ and urges Member States and regional organizations to render "assistance to migrants and victims of human trafficking recovered at sea, in accordance with international law". ${ }^{78}$

In light of the above, even though Operation Sophia was created as a military mission, its naval assets, when encountering people boats in distress at sea, have a positive obligation to rescue them. Several international treaties include provisions relating to a duty to render assistance at sea. The prevalence of treaties has been ascribed in part to the quite old but still well-known sinking of the Titanic, which raised demand for international cooperation in safety matters. The most widely applicable treaty rule, however, is Art. 98 of the UNCLOS:

Every State shall require the master of a ship flying its flag, in so far as he can do so without serious danger to the ship, the crew or the passengers:

(a) to render assistance to any person found at sea in danger of being lost;

(b) to proceed with all possible speed to the rescue of persons in distress, if informed of their need of assistance, in so far as such action may reasonably be expected of him;

(c) after a collision, to render assistance to the other ship, its crew and its passengers and, where possible, to inform the other ship of the name of his own ship, its port of registry and the nearest port at which it will call (emphasis added). ${ }^{79}$

According to this provision, every flag State must require the master of a vessel, whether a State or private vessel flying the State's flag, to proceed with all possible speed to the rescue of persons in peril when informed of their need for assistance or whenever there is reasonable grounds for retaining that they are threatened by a grave and imminent danger. This obligation is applicable to all vessels, and assistance must be provided to any person regardless of the nationality or status of such a person or the circumstances in which that person is found. Although this article is located in the UNCLOS section on the high seas, the duty to rescue applies in all maritime zones ${ }^{80}$ It is closely connected with the principle of safety of life at sea, which is the only real limit to the freedom of navigation on the high seas. Accordingly, and because of its repetition in treaty and domestic law and in State

\footnotetext{
${ }^{76}$ The International Convention on Maritime Search and Rescue, adopted 27 April 1979, in force 22 June 1985; 1405 UNTS No. 23489.

${ }^{77}$ See Resolution 2240 (2015), cit. preamble.

${ }^{78}$ IbId, para. 3.

${ }^{79}$ See Art. 98 UNCLOS.

${ }^{80}$ Among others, on the content of the duty to rescue at sea, see Pallis (2002), pp. 329-364; Trevisanut (2010), p. 523.
} 
practice, the duty to render assistance is generally recognized as a principle of customary law binding on all States. ${ }^{81}$

\section{The Search for Clarity on the Place of Safety}

Undertaking rescue operations does not exhaust the duty to render assistance. In this context, it is important to emphasize that this duty is only fully met if the rescued persons can disembark in a place of safety. In other words, following their rescue, survivors shall be conducted to a safe place. This complementary aspect seems implicit in the logic of any rescue attempt, which is to save lives. In practice, however, the prompt identification of a place of safety where irregular migrants rescued at sea can be disembarked is often quite problematic. The main challenge derives from the fact that while the obligation of States to rescue people at sea is, as seen above, a long-established rule of international customary law codified in a number of treaties, for disembarkation purposes a comparable binding provision does not exist in the law of the sea.

During the general revision of the International Maritime Organization's (IMO) SAR system, the IMO's Maritime Safety Committee (MSC) faced the problem of where rescued persons can and should be disembarked, without distinction based on their legal status, nationality, or place where they were found. ${ }^{82}$ The MSC adopted two Resolutions that entered into force on 1 July 2006 and amended the abovementioned SOLAS and SAR Conventions. In particular, following the amendments to these Conventions, people rescued at sea must be promptly conducted to a "place of safety," which is defined as follows:

[...] a place where the survivors' safety of life is no longer threatened and where their basic human needs (such as food, shelter and medical needs) can be met. Furthermore, it is a place from which transportation arrangements can be made for the survivors' next or final destination. ${ }^{83}$

According to the renewed SAR regime, making available a place of safety is the responsibility of the State in whose SAR zone the survivors are rescued. ${ }^{84}$ This rule, however, does not mean that this State or the intervening State is automatically obliged to disembark recovered people on their own territories. ${ }^{85}$ In theory, survivors can also be disembarked in a third country that is willing to receive them. In

\footnotetext{
${ }^{81}$ Ibid.

${ }^{82}$ See Tondini (2012), p. 59; Trevisanut (2010), cit.

${ }^{83}$ IMO-Maritime Safety Committee 'Guidelines on the treatment of persons rescued at sea' (MSC Guidelines) art 6.12 Resolution MSC.167(78) (20 May 2004) www.unhcr.org/refworld/docid/ 432acb464.html.

${ }^{84}$ Ibid Art. 2.5.

${ }^{85}$ On the obligation to render assistance at sea and on the responsibility for failing to save lives, see Papastavridis (2016a), pp. 31-47.
} 
practice, if compared to "ordinary" situations of distress at sea, the fact that the people in question are mainly represented by a large amount of undocumented migrants, refugees, and/or asylum seekers does not facilitate the disembarkation procedures. The combination of "irregular migrants" on the one hand and "distress" on the other hand tends to generate questionable dynamics of burden avoidance and burden shifting between States. ${ }^{86}$

While the amendments to the SAR and SOLAS Conventions decided by the IMO were aimed to guarantee assistance to rescued persons and, at the same time, to minimize negative consequences for the rescue vessel, it is clear that in practice the disembarkation burdens rest primarily upon the warship's flag State, with the SAR coordinating State concurring. When the latter is unable or unwilling to find a proper place of disembarkation, it is the warship's flag State that in the end must find an appropriate solution to the stalemate. ${ }^{87}$

In the current context of the Mediterranean migration crisis, the international practice and discussions around the follow-up of rescue operations at sea show how the SAR regime is under pressure due to the fact that the State accepting disembarkation is bound to assume responsibility of asylum seekers and to manage the presence of other migrants, with an irregular status as far as entry and stay are concerned. As Operation Sophia's assets are incidentally engaged in rescue operations, the legal issues relating to the prompt identification of a place of safety to disembark survivors rescued at sea assume renewed relevance. The key legal question we wish to focus on hereinafter concerns the criteria that can and should be applied to establish disembarkation procedures in the case of SAR interventions carried out by Eunavfor Med naval forces on the high seas and, eventually, in the Libyan territorial sea.

\subsection{On the High Seas}

In the Council Decision, the above-recalled Recital (6) stipulates that survivors must be delivered to "[...] a place of safety, and to that end the vessels assigned to Eunavfor Med will be ready and equipped to perform the related duties under the coordination of the competent Rescue Coordination Centre."

The generic rule entailed by the Council Decision is in line with the generic wording used in the Six Monthly Report in the section on "Cooperation with EU organizations and Agencies." 88 In this section, the Operation Commander clarifies to have with Frontex "a general agreement and specific operational Procedures". Such cooperation with Frontex led to the adoption of the operational coordination structures that have been formalized by means of an exchange of letters on 14 July 2015

\footnotetext{
${ }^{86}$ For an analysis of the disputes of Mediterranean States with regard to SAR operations, see Trevisanut (2010) cit.

${ }^{87}$ See Tondini (2012), p. 62, cit.

${ }^{88}$ The Six Monthly Report, p. 14.
} 
and the subsequent adoption of Standard Operating Procedures (SOPs) on 30 September 2015. The cooperation with this Agency shall cover, among other aspects, "the procedures for disembarkation in a place of safety." Furthermore, in the following section on "Cooperation with the Italian Authorities," Commander adds that "EUNAVFOR Med must comply with the EEAS (2015) 885 guidance to follow the TRITON Operation Plan for the disembarkation of persons rescued at sea." In addition, likewise generic is the official news reporting on Eunavfor Med rescue interventions. It refers to disembarkation either in Sicily ports or in an undefined place of safety. ${ }^{90}$

However, as far as we may understand from both the Council Decision and the Six Monthly Report - the EEAS (2015) 885 guidance is not publicly available-we presume that by virtue of this cooperation with Frontex and Italy, Eunavfor Med's operational plan and SOPs are in compliance with Triton's operational plan. The latter, in turn, must comply with the above-recalled Sea Border Regulation, which governs Frontex joint operations and includes specific modalities for the disembarkation of persons (intercepted or) rescued in a maritime operation. ${ }^{91}$ On this basis, we deem that the Sea Border Regulation applies also to disembarkation procedures undertaken within Operation Sophia's interventions on the high seas.

For a number of reasons, our interpretation would be well desirable. First, this Regulation expressly contemplates the specific case in which border surveillance operations at sea turn into rescue interventions. For these cases, recalling the content of the duty to rescue, provided for by Art. 98 UNCLOS, the Regulation stipulates as follows:

[...] every State must require the master of a vessel flying its flag, in so far as he can do so without serious danger to the vessel, the crew or the passengers, to render assistance without delay to any person found at sea in danger of being lost and to proceed with all possible speed to the rescue of persons in distress. Such assistance should be provided regardless of the nationality or status of the persons to be assisted or of the circumstances in which they are found. The shipmaster and crew should not face criminal penalties for the sole reason of having rescued persons in distress at sea and brought them to a place of safety. ${ }^{92}$

Second, when people are rescued, pursuant to Art. 10(c) of the Sea Border Regulation, the responsibility of the operational decision shall be shifted to the host State, which-both for Triton and Eunavfor Med operations-is Italy. This decision must be adopted in accordance both with the principle of nonrefoulement ${ }^{93}$ and the specific disembarkation modalities that would prevent

\footnotetext{
${ }^{89}$ The Six Monthly Report, p. 15.

${ }^{90}$ On more recent news, see EU External Action http://www.eeas.europa.eu/csdp/missions-andoperations/eunavfor-med/news/index_en.htm. Accessed 31 May 2016.

${ }^{91}$ See Regulation 656/2014, Art. 10.

${ }^{92}$ See Regulation 656/2014, Rec. 14.

${ }^{93}$ On the broad interpretation of the principle of non-refoulement, see the European Court of Human Rights, Hirsi Jamaa and others v. Italy, cit. For a comment, see Liguori (2012), p. 415. For doctrine on the implementation of the principle of non refoulement at sea, see Trevisanut (2008), pp. 205-246.
} 
naval units from transferring people (intercepted or) rescued at sea in a place where, inter alia, there is a serious risk that they would be subjected to the death penalty, torture, persecution, or other inhuman or degrading treatment or punishment or where their life or freedom would be threatened on account of their race, religion, nationality, sexual orientation, membership of a particular social group, or political opinion. ${ }^{94}$

Third, pursuant to Frontex' Annual Report on the implementation of the Sea Border Regulation, with respect to 2014, since handover and disembarkation in third countries were not foreseen in Triton's operational plan, "[a]ll the migrants intercepted or rescued were disembarked in Italy." 95

At the time of writing, the subsequent Frontex Annual Report concerning the implementation period of 2015 has not been published yet. However, from the cross-checked analysis of the puzzle of documents above recalled, we would conclude assuming that irregular migrants rescued on the high seas during SAR operations carried out within the Operation Sophia are disembarked in Italy, which may be considered a safe place.

\subsection{In the Libyan Territorial Sea}

Our interpretation is less optimistic if Phase 2-Libyan Territorial Sea begins. In this respect, while the Council Decision does not contain any specific information regarding how EU military forces shall act with irregular migrants saved by Sophia's units when the Operation patrols will begin to operate within Libyan territorial waters, from the Six Monthly Report emerges the idea that such forces shall interact and cooperate with the Libyan Navy and Coast Guard. In more detail, the Report clarifies that, if requested and if the operational mandate is amended, Eunavfor Med will provide Libyan forces operating at sea with capability and capacity building. Initially, this interaction in Libyan territorial waters would include Libyan "cooperation in tackling the irregular migration issue," with the expectation that at a later point in time "Libyan authorities could take the lead in patrolling and securing their Territorial Waters, with support being provided by EUNAVFOR Med." ${ }^{\circ 6}$

The illustrated scenario seems to be inspired by the bilateral agreements concluded by Spain with a number of States in Northwest Africa, including Morocco, Senegal, Mauritania, and the Cape Verde, which stipulate joint sea patrols of the Spanish Coast Guard and the border authorities of the partner States and which

\footnotetext{
${ }^{94}$ Ibid, Regulation 656/2014, Rec. 13.

${ }^{95}$ See Frontex' Annual Report on the implementation on the EU Regulation 656/2014 of the European Parliament and of the Council of 15 May 2014 establishing rules for the surveillance of the external sea borders. P. 7.

${ }^{96}$ See the Report, section Capacity and Capability Building, p. 20.
} 
intend to prevent people boats from exiting the territorial sea of the latter States. ${ }^{97}$ These agreements have been highly instrumental in closing the Atlantic migration route to the Canary Islands and continental Spain and have raised questions, among the other aspects, about the sharing of responsibilities between the various States involved in relation to the handover of intercepted migrants. ${ }^{98}$

Bearing in mind the issues raised by these arrangements, we fear that similar arrangements may be concluded with third States that may not be qualified as a safe place in accordance with the SOLAS and SAR Conventions and/or as a safe third country in accordance with the customary principle of nonrefoulement. ${ }^{99}$ Our fear, in particular, concerns the possible cooperation with Libya. In this regard, Frontex's past experience with the Triton Operation proves that Libyan authorities are not ready to cooperate. According to the abovementioned Frontex Annual Report, the Italian Rescue Coordination Center received several distress calls from people boats in Libyan SAR zone and even though the Triton operational area was extended up to the SAR regions of Italy and Malta, every attempt to communicate with Libyan SAR authorities was always denied. ${ }^{100}$

This may be probably explained once again by the above-recalled political crisis that has existed in Libya since 2014. Due to this crisis, in many parts of the State, Libyan authorities lack the capacity to effectively control the territory. They are basically omitting to adopt measures capable to prevent and repress on their territory a wide range of serious violent threats such as the rising trend of terrorist groups in Libya proclaiming allegiance to the Islamic State in Iraq and the Levant (also known as Da'esh) and the continued presence of other Al-Qaida-linked terrorist groups and individuals operating in Libya. ${ }^{101}$ Also, the area of Tripoli and its ports, from which most smugglers and traffickers depart, are subject to dangerous militias. Additional concerns regarding stability in Libya and in the Region derive from the uncontrolled proliferation of unsecured arms and ammunition. $^{102}$

Our conclusion is accordingly that the legality of SAR activities in Libyan territorial waters will depend on how rescued migrants will be processed and

\footnotetext{
${ }^{97}$ The agreements themselves are confidential. See for an extensive analysis Garcia Andrade (2010), pp. 311-346.

${ }^{98}$ Ibid.

${ }^{99}$ This principle of non-refoulement appears in several central instruments of international law. See, among others, Art. 33(1) of the Convention Relating to the Status of Refugees (opened for signature 28 July 1951, entered into force 22 April 1954) and Art. 3(1) of the Convention against Torture and Other Cruel, Inhuman or Degrading Treatment or Punishment (opened for signature 4 February 1985, entered into force 26 June 1987) 1465 UNTS 85 (CAT).

${ }^{100}$ See Frontex Annual Report, p. 7.

${ }^{101}$ On the use of force against terrorism and other violent activities of non-state actors in acquiescent States, see Tancredi (2007), p. 969 ff.

${ }^{102}$ On these grounds, the Security Council has affirmed that 'the situation in Libya constitutes a threat to international peace and security'. See Security Council Resolutions 2213 (2015) and 2238 (2015), cit.
} 
where they will be disembarked. EU Member States operating within Operation Sophia would necessarily be exercising effective control over migrants when operating unilaterally or jointly with Libyan forces within Libyan territorial waters, and EU Member States would therefore be bound by SAR regime and the nonrefoulement obligations. Moreover, this time it is hard to imagine that the Sea Border Regulation will be further geographically extended. Its provisions, indeed, are remarkably silent on SAR interventions in the territorial sea of third States, even though in earlier policy documents the intention was to clarify the scope of Member State powers also in respect of operations in the territorial sea of third countries. ${ }^{103}$

\section{Concluding Remarks}

When Frontex was created, the core of its mandate was described rather broadly as rendering "more effective the application of existing and future Community measures relating to the management of external borders." 104 Over the years, in the wake of frequent embarrassing shipwrecks, the EU approach vis-à-vis the phenomenon of immigration by sea has been slowly evolving toward the respect of migrants' fundamental rights and the inclusion of SAR activities in Frontex join operations.

With Operation Sophia, the idea was to adopt a new strategy. In addition to Frontex joint operations-which nevertheless remain primarily focused on border management - the EU is now committed to a military mission, having the specific goal of disrupting migrant smuggling and human trafficking routes and capabilities. In effect, these transnational organizations play a crucial role in the current escalation of migratory movements toward Europe. But, even if illegally, the fact is that they represent the sole route available to escape hunger, civil wars, and other unimaginable situations in their countries of origin.

The extraordinary situation in the Mediterranean led also the Security Council to intervene and, specifically, to make use of the powers granted by Chapter VII of the UN Charter in order to authorize Member States and international organizations to use enforcement jurisdiction against irregular migration on the high seas. ${ }^{105}$ With regard to this maritime zone, however, States are already provided with sufficient coercive powers by virtue of the applicable international legal framework, including Art. 110 UNCLOS and Art. 8 of the Protocol against the Smuggling of Migrants. Therefore, what is currently really needed to activate what is deemed to be the crucial phase of Operation Sophia is the consent of an effective Libyan government.

\footnotetext{
${ }^{103}$ See $\operatorname{COM}(2006), 733$ final, par. 34. For doctrine, see M. den Heijer, "How the Frontex Sea Borders Regulation avoids the hot potatoes", cit.

${ }^{104}$ See Reg. 2007/2004, Art. 1(2).

${ }^{105}$ See Resolution 2240 (2015).
} 
The recent UN-led formation of a government of national unity may slowly go in this direction. In fact, based on the readiness expressed by the President of the Presidency Council of the Libyan Government of National Accord to cooperate with the EU, the latter went ahead with the militarization of the waters off the coast of Libya. ${ }^{106}$ Last June, the Operation Sophia's mandate was extended until 27 July 2017 with two additional assignments: the assistance in the development of the capacities and in the training of the Libyan Coast Guard and Navy in law enforcement tasks and the implementation of the UN arms embargo ${ }^{107}$ on the high seas off the coast of Libya. Meanwhile, however, while both the EU and the UN remain focused on fighting criminal networks, it persists the primary humanitarian need of saving migrants' lives at sea. This old problem affected and affects many coastal States in the world. Already in the mid-1970s, for instance, many boat people fled from the communist regime in Vietnam. By the end of the 1980s, the number of people fleeing Vietnam was increasing and, in parallel, the willingness of host States in the region to offer protection and of third countries outside the region to offer resettlement was declining. ${ }^{108}$ In the context of the Mediterranean migration crisis, the need to render assistance to migrants in danger at sea is unfortunately more evident by frequent mass drownings. This is an urgent need and also a positive obligation binding on all States.

Against this factual and legal backdrop, both Frontex and Eunavfor Med operations, even if initially and primarily focused on different objectives, have incidentally turned into rescue operations. This reaction is certainly appreciated under a humanitarian perspective. But, facing the increasing number of deaths at sea, we hardly understand the reasons why SAR interventions are still adopted incidentally, rather than officially and on a regular basis. The rescue of irregular migrants at sea, indeed, requires the adoption and the implementation of an appropriate legal regime. From the chapter arises the importance of relying on clear and transparent criteria to govern operational decisions concerning the disembarkation of rescued migrants in a safe place. The crossed interpretation of a number of EU legal and operational documents on Operation Sophia led us to argue that to SAR interventions on the high seas applies the Sea Border Regulation. Should our interpretation be correct, each operational decision to establish the place of disembarkation would

\footnotetext{
${ }^{106}$ See the Council Decision (CFSP) 2016/993 of 20 June 2016 amending Decision (CFSP) 2015/ 778 on a European Union military operation in the Southern Central Mediterranean, OJ L 162/18 of 21 June 2016.

${ }^{107}$ On 14 June 2016, the UN Security Council adopted the Resolution 2292 (2016) on the arms embargo on Libya, expressing in particular concern that the situation in Libya is exacerbated by the smuggling of illegal arms and related materiel. Pursuant to this Resolution, Member States are authorized 'to inspect [...] on the high seas off the coast of Libya, vessels bound to or from Libya which they have reasonable grounds to believe are carrying arms or related materiel to or from Libya [...]'. With previous resolutions, the Security Council has imposed, modified and reaffirmed the arms embargo in Libya. See resolutions 1970 (2011), 1973 (2011), 2009 (2011), 2040 (2012), 2095 (2013), 2144 (2014), 2174 (2014), 2213 (2015), 2214 (2015) and 2278 (2016).

${ }^{108}$ Coppens and Somers (2010), pp. 377-403.
} 
be taken by the Italian Rescue Coordination Center. The latter shall act and decide in compliance with the migrants' fundamental rights and the disembarkation procedures laid down in the Regulation itself. Nevertheless, we stress that this is only a presumption, a desirable presumption that would need to be confirmed by official sources.

Lack of clarity concerns also the possible activation of Phase 2-Libyan Territorial Sea. After a number of mistakes, however, we cannot forget the negative effects of the patrol agreements between Spain and a number of States in Northwest Africa, the difficult experience of Triton with Libyan authorities, and, above all, the grave political situation in Libya. Against these factors, the intention to cooperate with Libyan enforcement authorities is induced to skepticism in terms of possible violations of the legal framework on the identification of a safe place in accordance with the UNCLOS, SOLAS, and SAR Conventions and/or a safe third country in accordance with the principle of nonrefoulement.

An extensive application of the Sea Border Regulation to every operation of the EU and its Member States must be more intensively considered together with an extensive cooperation with more stable and reliable States.

\section{References}

Andreone G (2011) Immigrazione clandestina, zona contigua e Cassazione italiana: il mistero si infittisce. Diritti Umani e Diritto Internazionale 5(1):183-188

Andreone G (2014) Chronique de la Jurisprudence. Annuaire du Droit de la Mer 2013, 63

Borelli S, Stanford B (2014) Troubled waters in the Mare Nostrum: interception and push-backs of migrants in the Mediterranean and the European Convention on Human Rights. Rev Int Law Polit 10:29-69

Butler G, Ratcovich M (2016) Operation Sophia in uncharted waters: European and international law challenges for the EU Naval Mission in the Mediterranean Sea. Nord J Int Law 85:235-259

Carrera S, den Hertog L (2016) A European border and coast guard: what's in a name? Liberty Secur Europe 88:1-20

Cataldi G (2015) Giurisdizione e intervento in alto mare su navi impegnate nel traffico di migranti. Giurisprudenza italiana 167(6):1498-1502

Conforti B, Focarelli C (2015) Nazioni Unite. Cedam Wolters Kluwer, Milan

Coppens J, Somers E (2010) Towards new rules on disembarkation of persons rescued at sea? Int J Mar Coastal Law 25:377-403

Court of Justice of the European Union, Judgment of 5 September 2012, Case C-355/10, Parliament $v$ Council, par. 65-85

den Heijer M (2016) Frontex and the shifting approaches to boat migration in the European Union; a legal analysis. In: Zaiotti R (ed) Externalizing migration management Europe, North America and the spread of 'remote control' practices. Routledge, London, pp 53-71

Corte di Cassazione, judgment of 23 May 2014, No. 36052

European Court of Human Rights, Hirsi Jamaa and others v. Italy, Judgment of 23 February 2012

European Court of Human Rights, Sufi and Elmi vs. United Kingdon, Apps. No. 8319/07 and $11449 / 07$, concerning the appeal by two Somali citizens at risk of inhumane treatment if returned to Mogadishu 
Garcia Andrade P (2010) Extraterritorial strategies to tackle irregular immigration by sea: a Spanish perspective. In: Ryan B, Mitsilegas V (eds) Extraterritorial immigration control. Legal challenges. Martinus Nijhoff, Leiden, pp 311-346

Geiss R, Petrig A (2011) Piracy and armed robbery at sea, the legal framework of counter-piracy operations in Somalia and the Gulf of Aden. Oxford University Press, Oxford

Gordon R (1997) Saving failed states: sometimes a neocolonialist notion. Am Univ Int Law Rev 12(6):903-974

Guilfoyle G (2009) Shipping interdiction and the law of the Sea. Cambridge University Press, New York

International Tribunal for the Law of the Sea, The M/V "Saiga" (No. 2) Case (Saint Vincent and the Grenadines v. Guinea), Judgment of 1 July 1999D

Italian Supreme Court, Criminal proceedings against Radouan Hai Hammouda, No. 3345, 23 January 2015

Kreijen G (2004) State failure, sovereignty and effectiveness: legal lessons from the decolonization of sub-Saharan Africa. Brill/Academic, Leiden/Boston

Lehmann J (2015) the use of force against people smugglers: conflicts with refugee law and human rights law. In: EJIL:Talk! Blog of the European Journal of International Law. Available via EJIL:Talk! http://www.ejiltalk.org/the-use-of-force-against-people-smugglers-conflicts-withrefugee-law-and-human-rights-law/. Accessed 31 May 2016

Liguori A (2012) La Corte europea dei diritti dell'uomo condanna l'Italia per i respingimenti verso la Libia del 2009: il caso Hirsi. Rivista di diritto internazionale 95(2):415-443

Pallis M (2002) Obligations of states towards asylum seekers at sea; interactions and conflicts between legal regimes. Int J Refugee Law 14(2/3):329-364

Papanicolopulu I (2016) Immigrazione irregolare via mare ed esercizio della giurisdizione: il contesto normativo internazionale e la recente prassi italiana. In: Antonucci A, Papanicolopulu I, Scovazzi T (eds) L'immigrazione irregolare via mare nella giurisprudenza italiana e nell'esperienza europea, 1st edn. G Giappichelli Editore, Torino, pp 2-22

Papastavridis ED (2016a) The forgotten responsibilities of the flag state to save people at sea. In: Nikodinovska Krstevska A, Tushevska Gavrilovikj B (eds) Migration at sea. International law perspectives and regional approaches, 1st edn. Giannini, Napoli, pp 31-47

Papastavridis ED (2016b) EUNAVFOR MED Operation Sophia and the question of jurisdiction over transnational organized crime at sea In: Questions of International Law. Available via QIL: http://www.qil-qdi.org/eunavfor-med-operation-sophia-question-jurisdiction-transna tional-organized-crime-sea/

Picone P (2015) Gli obblighi erga omnes tra passato e futuro. In: Interesse collettivo e obblighi erga omnes nel diritto internazionale contemporaneo. In: Questions of International Law. Available via QIL: http://www.qil-qdi.org/wp-content/uploads/2015/07/Picone_Gli-obblighierga-omnes-tra-passato-e-futuro.pdf. Accessed 31 May 2016

Ringbom H (2015) Jurisdiction over ships: post-UNCLOS developments in the law of the sea. Brill, Leiden

Scarpa S (2008) Trafficking in human beings: modern slavery. Oxford Scholarship Online

Scovazzi T (2014) Human rights and immigration at sea. In: Rubio-Marín R (ed) Human rights and immigration, 1st edn. Oxford University Press, New York, pp 212-260

Siller N (2016) 'Modern Slavery' does international law distinguish between slavery, enslavement and trafficking? J Int Crim Justice 14:405-427

Tancredi A (2007) Il problema della legittima difesa nei confronti di milizie non statali alla luce dell'ultima crisi tra Israele e Libano. Rivista di diritto internazionale 90(4):969-1007

Tancredi A (2008) Di pirati e stati "falliti": il Consiglio di sicurezza autorizza il ricorso alla forza nelle acque territoriali della Somalia. Rivista di diritto internazionale 91(4):937-966

Tondini M (2012) The legality of intercepting boatpeople under search and rescue and border control operations. J Int Marit Law 18:59-74

Treves T (2009) Piracy, law of the sea, and use of force: developments off the coast of Somalia. Eur J Int Law 20(2):399-414 
Trevisanut S (2008) The principle of non refoulement at sea and the effectiveness of asylum protection. Max Planck Yearbook United Nations Law 12:205-246

Trevisanut S (2010) Search and rescue operations in the Mediterranean: factor of cooperation or conflict? Int J Mar Coastal Law 25:523-542

Trevisanut S (2012) Immigrazione irregolare via mare. Diritto internazionale e diritto dell'Unione Europea, Jovene Editore, Napoli

Wippman D (1996-1997) Military intervention, regional organizations, and host-state consent. Duke J Comp Int Law 7:209-239

Open Access This chapter is licensed under the terms of the Creative Commons AttributionNonCommercial 4.0 International License (http://creativecommons.org/licenses/by-nc/4.0/), which permits any noncommercial use, sharing, adaptation, distribution and reproduction in any medium or format, as long as you give appropriate credit to the original author(s) and the source, provide a link to the Creative Commons license and indicate if changes were made.

The images or other third party material in this chapter are included in the chapter's Creative Commons license, unless indicated otherwise in a credit line to the material. If material is not included in the chapter's Creative Commons license and your intended use is not permitted by statutory regulation or exceeds the permitted use, you will need to obtain permission directly from the copyright holder. 